\title{
Anticancer Activity of Biosynthesized Silver Nanoparticles using Murraya koenigii Leaf Extract against HT-29 Colon Cancer Cell Line
}

Kadheeja Roshni, Mohd Younis, Ilakkiyapavai D, Preethi Basavaraju and Vinayaga Moorthi Puthamohan*

Department of Human Genetics and Molecular Biology, Bharathiar University, Coimbatore, Tamil Nadu, India

\begin{abstract}
Plants extract from Murraya koenigii was used for the synthesis of silver nanoparticles (Ag NPs) using silver nitrate solution. Ag NPs were characterized by UV-vis spectrophotometer, scanning electron microscope (SEM), Energy Dispersive Spectroscopy (EDX) and Fourier Transform Infra-Red Spectroscopy (FT-IR). The formation of stable silver nanoparticles reduced to the colloidal solution are observed by UV-vis spectrophotometer analysis. SEM determination of the brown coloured samples with well dispersed nanoparticles seen after treatment with silver nitrate showed the presence of silver nanoparticle whereas the EDX analysis performed is to confirm the presence of silver molecules in the sample and FTIR measurement carried out identifies the biomolecules present in $M$. koenigii leaf responsible for capping leading to efficient stabilization of the silver nanoparticles. The anticancer potential of the nanoparticles was evaluated using MTT assay on HT-29 colon cancer cell line. Ag NPs showed potent cytotoxic activity against the human colorectal adenocarcinoma (HT-29) cell line at higher concentrations. This study insights the M. koenigii synthesized silver NP's could be an effective applicability drug candidate for colon cancer.
\end{abstract}

Keywords: Plants extract; Murraya koenigii; Silver nanoparticles; Colon cancer and HT-29

\section{Introduction}

Cancer, a disease of uncontrolled growth of the cell, inhabits all anatomical structures of human beings and changes their phenotypic and physiological condition. In human is due to the accrual of genetic alterations/mutations Bienz and Clevers [1]. Tobacco usage remains as the first and most important identified risk factor for cancer. It is now known that over one-third of cancers are preventable, and onethird potentially curable provided they are diagnosed early in their course [2]. Colorectal Cancer (CRC), one type of cancer that affects the colon of the human. Based on the pathways, including chromosomal and microsatellite instability, $\mathrm{CpG}$ island methylator phenotype, genomic mutations, micro RNA and epigenetic changes Kanthan [3] were utilized for the formation and development of CRC Ewing [4] stated that, CRC was due to aggregation of mutations at the genetic level. In India, it was estimated that, 4.4 and 4.1 men per lakh were affected by the colon and rectal cancer, respectively, according to annual incidence rate (AAR). It was also estimated that, prevalence of colon cancer was 3.9 per one lakh women. In the ranking, colon and rectal cancer occupied 8 and 9 th position in men. It is the third most common cancer in men $(6,63,000$ cases, $10.0 \%$ of all cancer cases) and the second most common in women $(5,71,000$ cases, $9.4 \%$ of all cancer cases) worldwide. In India, the annual incidence rates (AARs) for colon cancer and rectal cancer in men are 4.4 and 4.1 per 1,00,000, respectively. The AAR for colon cancer in women is 3.9 per $1,00,000$. In the 2013 report, the highest AAR in men for CRCs was recorded in Thiruvananthapuram - 4.1 followed by Bangalore - 3.9 and Mumbai - 3.7. The highest AAR in women for CRCs was recorded in Nagaland5.2 followed by Aizwal - 4.5 Sirohi [5].

A nanoparticle, the nucleus of nanotechnology, has been vastly being employed for the effective control of cancer cell lines as prominent therapeutic agents. There are number of synthesis procedure has been emerged so far but use of flora-based extracts for nanoparticle synthesis have been more advantageous than microbial process Narayanan and Sakthi [6] and it's an ideal candidate for large scale production $[7,8]$. Rajendra Prasad, Chang, Guerriero demonstrated the anti- carcinogenic potential of caffeic acid against different cancer cell lines [9-11]. Devi and Bhimba [12] reported the anticancer properties of Ulva lactuca against human cancer cell line such as Hep2, MCF7 and HT-29. Moorthi evaluated bioactivity of silver nanoparticle synthesized from Sargassum muticum [13].

P53 gene located in chromosome $17 \mathrm{p}$ is found in up to $75 \%$ of cases of colorectal cancer. It is a tumor suppressor gene encodes a nuclear protein that functions as a transcription factor. p53 is regarded as one of the most important tumour suppressor genes with a key number of cellular functions such as DNA damage repair, initiation of programmed cell death and cell cycle checkpoint control.

Loss of material from the long arm of chromosome 18 is found in approximately $70 \%$ of cases of colorectal cancer and $50 \%$ of adenomas. The $18 \mathrm{q}$ segment contains three candidate tumour suppressor genes: DCC (deleted in colon cancer gene) and Smad 2 and Smad 4 (initially described as DPC4) genes. These proteins are involved in signalling from TGF- $\beta$ receptors and regulate transcription of key target genes such as c-myc, CBFA1, FLRF and furin McDermott [14].

\section{Materials and Methods}

In an Erlenmeyer's flask, $95 \mathrm{~mL}$ of $1 \mathrm{mM}$ Silver nitrate $\left(\mathrm{AgNO}_{3}\right)$ solution was prepared using chemical synthesis method, and the characterization of silver nanoparticles was performed in sequence using UV-Spectrophotometer, Scanning Electron Microscope (SEM).

*Corresponding author: Vinayaga Moorthi Puthamohan, Department of Human Genetics and Molecular Biology, Bharathiar University, Coimbatore, Tamil Nadu, India, Tel: +04222422222; E-mail: vinayputhu@gmail.com

Received December 25, 2017; Accepted April 04, 2018; Published April 06, 2018

Citation: Roshni K, Younis M, llakkiyapavai D, Basavaraju P, Puthamohan VM (2018) Anticancer Activity of Biosynthesized Silver Nanoparticles using Murraya koenigii Leaf Extract against HT-29 Colon Cancer Cell Line. J Cancer Sci Ther 10: 072-075. doi: 10.4172/1948-5956.1000521

Copyright: $\odot 2018$ Roshni K, et al. This is an open-access article distributed under the terms of the Creative Commons Attribution License, which permits unrestricted use, distribution, and reproduction in any medium, provided the original author and source are credited. 
The morphological and chemical nature of the NPs has been identified by using instrumentations such as X-ray diffraction etc. A fraction of aqueous extract of $M$. koenigii was subjected to phytochemical screening as described by Harborne [15] to find presence of Carbohydrate, Coumarins, steroids, Phytosterols, Triterpenoidalsapogenins, Xanthoproteins, reducing sugar, saponins, Tannins, Alkaloids. The Cytotoxic Assay screening was performed using MTT assay as per Mosmann [16] method to test the cytotoxicity of $M$. koenigii synthesised silver nanoparticles against HT-29, the colon cancer cell line.

Synthesis of silver nanoparticles using the curry leaf, M. koenigii was carried out in present study. Synthesis of atomic silver was achieved within 15 minutes of incubation at $90^{\circ} \mathrm{C}$. The change of the colour of the medium containing aqueous extract of $M$. koenigii and AgNO3 at the initial as well as in the endpoint was depicted in Figures 1A-1C. The change in the colour from colourless to dark brown was often indicates the excitation of surface plasmon resonance due to reduction of silver nitrate to atomic silver. The light absorption pattern of synthesized nanoparticle was examined using UV-spectrophotometer (JASCO, V630, and Japan) in a range of wavelength from 200 to $800 \mathrm{~nm}$.

The absorption maximum at $428 \mathrm{~nm}$ in the UV-spectrophotometer (Figure 2) represents the longitudinal plasmon vibration corresponding to silver nanoparticles. A sharp increase in the intensity of the peak without any shift in the peak position was observed upon varying time. This often evidenced the perfect interaction exists between silver ion
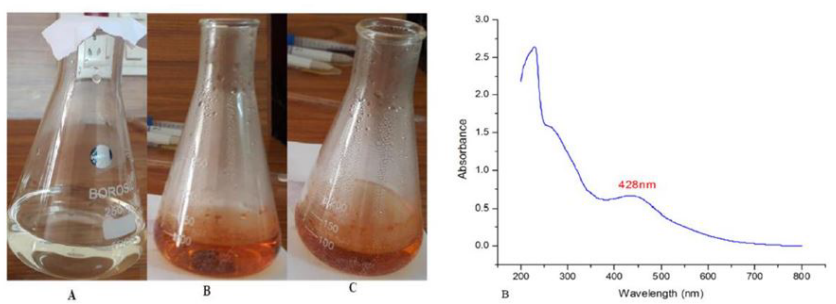

Figure 1: Synthesis of nanoparticles from the leaf extract of Murraya koenigii. (A-C) Change of color during reduction of $\mathrm{AgNO}_{3}$ to $\mathrm{Ag}$. (B) UV-Vis spectra of excitation peak of $\mathrm{Ag}$.

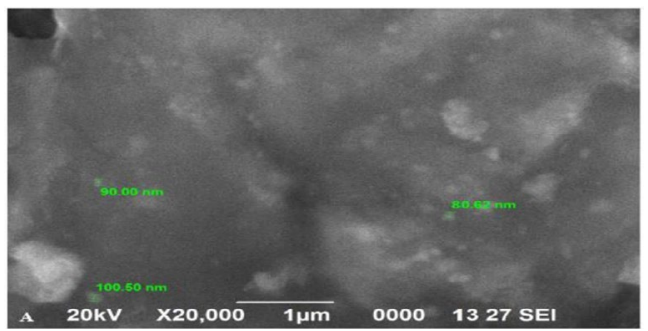

Figure 2: Scanning Electron Microscope (SEM) Image of silver nanoparticles synthesized from Murraya koenigii leaf aqueous extract.

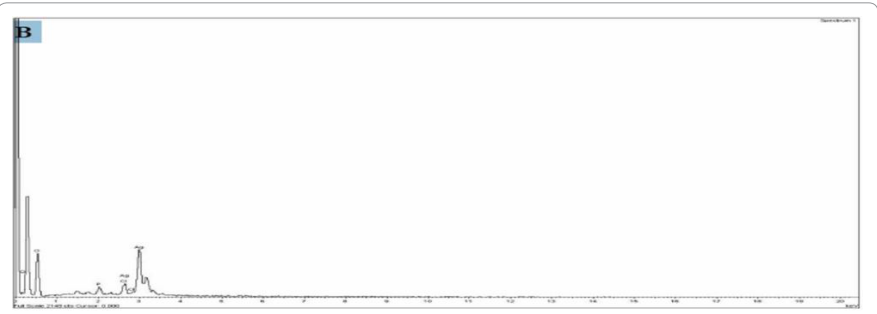

Figure 3: Energy Dispersive X-ray Spectroscopy (EDX) of silver nanoparticles synthesized from Murraya koenigii leaf aqueous extract.

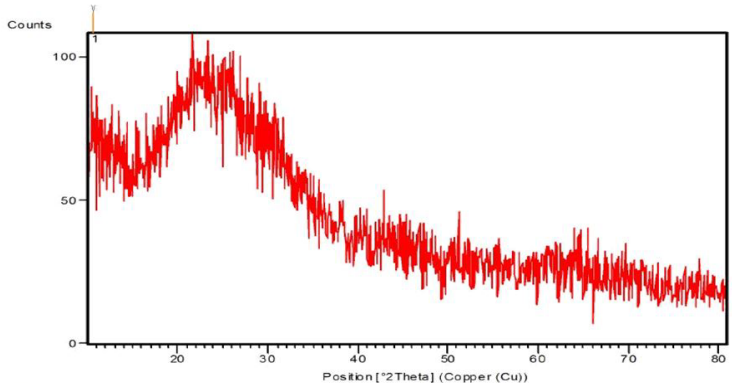

Figure 4: X-Ray dispersive spectra of silver nanoparticles synthesized from leaf extract of Murraya Koenigii.

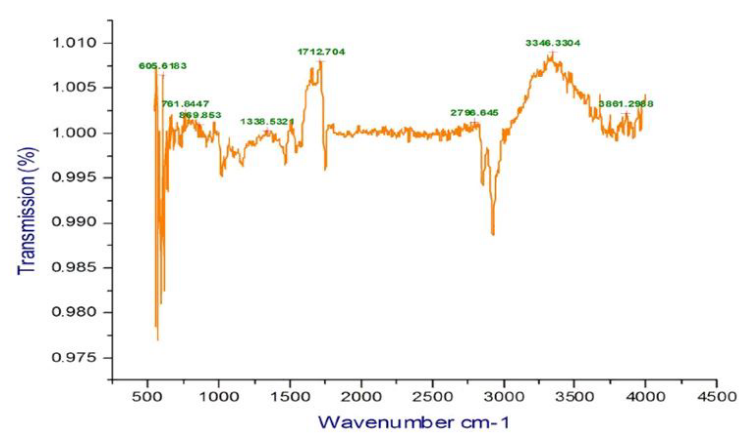

Figure 5: Fourier Transform-Infra Red (FT-IR) spectra of silver nanoparticles synthesized from leaf extract of Murraya Koenigii.

and phytochemicals of the aqueous extract of the M. koenigii. Besides that, their presence has been well defined in SEM image (Figure 3) and was of spherical in shape ranging from 80.62 to $100.50 \mathrm{~nm}$. The presence of silver was confirmed in EDX (Figure 3). In the FT-IR spectrum (Figure 4), intense peaks were observed for silver nanoparticles at $605.6183 \mathrm{~cm}^{-1}, 761.84 \mathrm{~cm}^{-1}, 869.85 \mathrm{~cm}^{-1}, 1338.53 \mathrm{~cm}^{-1}, 1712.70 \mathrm{~cm}^{-1}$, $2796.64 \mathrm{~cm}^{-1}, 3346.33 \mathrm{~cm}^{-1}$ and $3861.29 \mathrm{~cm}^{-1}$. The cytotoxic assay of silver nanoparticles against HT-29, the colon cancer cell line revealed excellent anticancer potential of the nanoparticles and the IC50 value was $26.05 \mu \mathrm{g} / \mathrm{mL}$.

\section{Discussion}

The current study revealed that, the synthesis of silver nanoparticle was morphologically visualized in UV-Vis spectrum (Figure 2), with a potent peak observed at $428 \mathrm{~nm}$, which is a characteristic of Ag nanoparticle and is confirmed in SEM analysis (Figure 3). Philip observed excitation at 432, 413 and $411 \mathrm{~nm}$ for colloids S1, S2 and S3, respectively. A similar study by Sajeshkumar [17] also reported that similar excitation at $435 \mathrm{~nm}$ for $M$. koenigii and also observed spherical shaped nanoparticles in SEM. Logeswari [18] observed maximum peak at $420 \mathrm{~nm}$ for silver nanoparticles synthesized by Ocimumtenuiflorum, Solanumtricobatum, Syzygiumcumini, Centellaasiatica and Citrus sinensis.

FTIR measurements were carried out to identify the possible biomolecules in M. Koenigii leaf responsible for capping leading to efficient stabilization of the silver nanoparticles. The IR spectrum (Figures 4 and 5) of silver nanoparticles manifests prominent absorption bands located at $605.6183 \mathrm{~cm}^{-1}, 761.84 \mathrm{~cm}^{-1}, 869.85 \mathrm{~cm}^{-1}$, $1338.53 \mathrm{~cm}^{-1}, 1712.70 \mathrm{~cm}^{-1}, 2796.64 \mathrm{~cm}^{-1}, 3346.33 \mathrm{~cm}^{-1}$ and 3861.29 $\mathrm{cm}^{-1}$. Philip [19] observed the IR spectrum of silver nanoparticles at $3412,2918,2849,1636,1539,1454,1375,1233,1154$ and $1031 \mathrm{~cm}^{-1}$. 

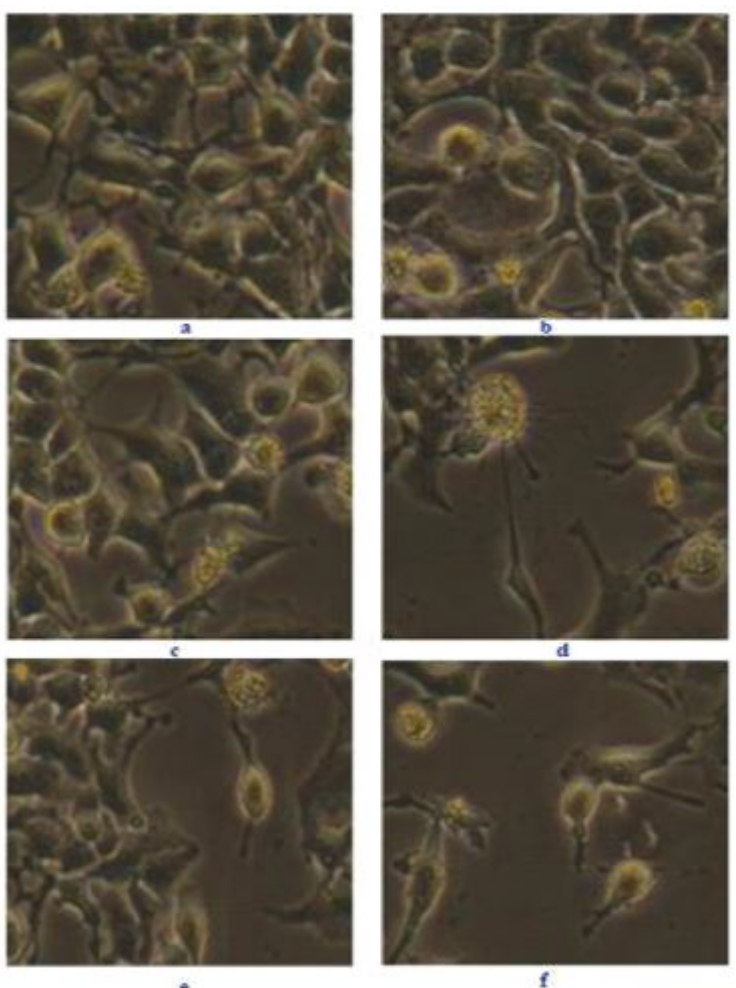

Figure 6: Cytotoxic activity of silver nanoparticles synthesized from leaf extract of Murraya Koenigii against $\mathrm{HT}=29$, the colon cancer cell line. a: Control; b-f: HT-29 colon cancer cell line treated with $(1.88,7.5,15$ and $30 \mu \mathrm{g})$ different concentrations of silver nanoparticles. nthesized from leaf extract of Murraya Koenigii.

The nanoparticle synthesized was subjected for its anticancer activity against HT 29 (Colon cancer cell line) and found IC50 value of 26.05 $\mu \mathrm{g} / \mathrm{mL}$ and almost $80 \%$ reduction in cell survival was noticed during the investigation [20].

The anticancer activity of Ag Nps was highly supported by the works of Prabhu [21]. In the present study, IC50 value obtained was low compared to Nayak [22] who reported IC50 value of $82.39,83.57$ and $78.78 \mu \mathrm{g} / \mathrm{mL}$ by AgNps synthesized from Cucubita maxima, Moringaoleifera and Acoruscalamus respectively. In contrast to Nayak et al. (2015), the present study reported the potent anticancer activity of leaf extract synthesized nanoparticle (Figure 6) [23-26].

The cytotoxicity of silver nanoparticles was due to introduction of reactive oxygen species (ROS) which enunciate the apoptosis pathway and its well established mitochondrial interaction. Besides, emanation of oxidative stress pronounced the genotoxic stress as well as $p 53$ gene up regulation Setyawati [27] which initiate the apoptosis. It has greatly supported the recommendation of nanomaterials for the anticancer studies. Hence, it was observed from the present investigation that, the cytotoxic activity of silver nanoparticle synthesized from curry leaf samples. It would be further studied for its mode of penetration and suppression of cancer cell line and regulation of genes of guardian of cells.

\section{Conclusion}

The rapid biological synthesis of silver nanoparticles using $M$. koenigii leaves extract provides eco-friendly, simple and efficient route for synthesis of benign nanoparticles. The results show that $M$. koenigii leaves play key roles in the reduction and stabilization of silver to silver nanoparticles. Physical characteristics of silver nanoparticles, such as shape and size, are important for reducing free radicals and cancer cell toxicities. The synthesized particles ranged in size from 80.62 to 100.50 $\mathrm{nm}$ and were spherical in shape, as shown by the SEM analysis and the presence of silver was confirmed in EDX. This characterisation is of use for large scale silver nanoparticle production, and could result in economic viability, as well as being eco-friendly for cancer treatment, drug delivery, sensors and commercial appliances and other medical and electronic applications. Silver nanoparticles might be useful for the development of newer and more potent antioxidants and anticancer agents. The biologically synthesized silver nanoparticles could be of immense use in medical field for their efficient anticancer function.

\section{References}

1. Bienz M, Clevers $H(2000)$ Linking colorectal cancer to Wnt Signaling Review. Cell 103: 311-320.

2. Nair MK, Varghese C, Swaminathan R (2015) Cancer: Current scenario intervention strategies and projections for 2015. http://www.searo.who.int/ india/topics/cancer/Cancer_resource_Commision_on_Macroec onomic_and Health_Bg_P2_Cancers_current_scenario.pdf. Accessed March 23, $201 \overline{6}$.

3. Kanthan R, Senger JL, Kanthan SC (2012) Molecular events in primary and metastatic colorectal carcinoma: a review. Patholog Res Int 1-14.

4. Ewing I, Hurley J, Josephides E, Millar A (2014) The molecular genetics of colorectal cancer. Frontline Gastroenterol 5: 26-30.

5. Sirohi B, Shrikhande SV, Perakath B, Raghunandharao D, Julka PK, et al. (2014) Indian Council of Medical Research consensus document for the management of colorectal cancer. Indian J Med Paediatr Oncol 35: 192-196.

6. Narayanan KB, Sakthivel N (2010) Biological synthesis of metal nanoparticles by microbes. Adv Colloid Interface Sci 156: 1-13.

7. Iravani I (2011) Green synthesis of metal nanoparticles using plants. Green Chem 13: 2638-2650.

8. Akhtar MS, Panwar J, Yun YS (2013) Biogenic synthesis of metallic nanoparticles by plant extracts. ACS Sustain Chem Eng 1: 591-602.

9. Rajendra Prasad N, Karthikeyan A, Karthikeyan S, Reddy BV (2011) Inhibitory effect of caffeic acid on cancer cell proliferation by oxidative mechanism in human HT-1080 fibrosarcoma cell line. Mol Cell Biochem 349: 11-19.

10. Chang CC, Hsu WH, Wang CC, Chou CH, Kuo MY, et al. (2013) Connective tissue growth factor activates pluripotency genes and mesenchymal-epithelial transition in head and neck cancer cells. Cancer Res 73: 4147-4157.

11. Guerriero JL, Ditsworth D, Catanzaro JM, Sabino G, Furie MB, et al. (2011) DNA alkylating therapy induces tumor regression through an HMGB1-Mediated activation of innate immunity. J Immunol 186: 3517-3526.

12. Devi JS, Bhimba BV (2012) Silver nanoparticles: Anti-Bacterial and invitro cytotoxic activity. IJBEES 2: 2277-4394.

13. Moorthi PV, Balasubramanian C (1983) Antimicrobial properties of marine seaweed, sargassum muticum against human pathogens. J Immuol Methods 65: 55-63.

14. McDermott U, Longley DB, Johnston PG (2002) Molecular and biochemical markers in colorectal cancer. Ann Oncol 4: 235-245.

15. Harborne JB (1984) Phytochemical methods (2nd edn), London and New York, USA.

16. Mosmann T (1983) Rapid colorimetric assay for cellular growth and survival: to application to proliferation and cytotoxic assays. J Immunol Methods 65: 55-63.

17. Sajeshkumar NK, Jose P, Mathew J, Sebastin A (2015) Synthesis of silver nanoparticles from curry leaf (Murraya koenigii) extract and its antibacterial activity. CIB Tech J Pharm Sci 4: 15-25.

18. Logeswari P, Silambarasan S, Abraham J (2015) Synthesis of silver nanoparticles using plants extract and analysis of their antimicrobial property. $J$ Saudi Chem Soc 19: 311-317.

19. Philip D, Unni C, Aromal SA, Vidhu VK (2011) Murraya koenigii leaf-assisted rapid green synthesis of silver and gold Nanoparticles. Spectrochim Acta Mol Biomol Spectrosc 78: 899-904. 
Citation: Roshni K, Younis M, llakkiyapavai D, Basavaraju P, Puthamohan VM (2018) Anticancer Activity of Biosynthesized Silver Nanoparticles using Murraya koenigii Leaf Extract against HT-29 Colon Cancer Cell Line. J Cancer Sci Ther 10: 072-075. doi: 10.4172/1948-5956.1000521

20. Moorthi V, Balasubramanian C (2015) Sargassum muticum against human pathogens. J Coast Life Med 3: 122-125.

21. Prabhu D, Arulvasu C, Babu G, Manikandan R, Srinivasan P (2013) Biologically synthesized green silver nanoparticles from leaf extract of Vitex negundo $L$. induce growth-inhibitory effect on human colon cancer cell lineHCT15. J Proc Bio 48: 317-324.

22. Nayak D, Pradhan S, Ashe S, Rauta PR, Nayak B (2015) Biologically synthesised silver nanoparticles from three diverse families of plant extracts and their anticancer activity against epidermoid A431 carcinoma. J Colloid Interface Sci 457: 329-338.

23. Asharani PV, Hande MP, Valiyaveettil S (2009) Anti-proliferative activity of silver nanoparticles. BMC Cell Biol 10: 1471-2121.
24. Sanpui P, Chattopadhyay A, Ghosh SS (2011) Induction of apoptosis in cance cells at low silver nanoparticle concentrations using chitosan nanocarrier. ACS Appl Mater Interfaces 3: 218-228.

25. Setyawati MI, Xun Y, Jianping X, David TL (2014) The influence of lysosomal stability of silver nanomaterials on their toxicity to human cells. Biomaterials 35: 6707-6715.

26. SetyawaGuo Q, Guo Q, Yuan J, Zeng J (2014) Biosynthesis of gold nanoparticles using a kind of flavonol: Dihydromyricetin. Colloids and Surfaces. Physicochemical and Engineering Aspects 441: 127-132.

27. ti MI, Tay CY, Leong DT (2013) Effect of zinc oxide nanomaterials-induced oxidative stress on the p53 pathway. Biomaterials 34: 10133-10142. 